\title{
Daddy Issues in J. M. Coetzee's In the Heart of the Country
}

\author{
Dwi Setiawan \\ Liliek S. Yuwono \\ English Department, Faculty of Letters, Petra Christian University, \\ Siwalankerto 121-131, Surabaya 60236, East Java, Indonesia \\ e-mails: dewey@peter.petra.ac.id \\ lsyuwono@peter.petra.ac.id
}

\begin{abstract}
In this article, we try to explore the psychological problems of Magda, the main female character in J.M. Coetzee's In the Heart of the Country, and the causes of the disorders. Using the theories of Oedipus Complex in females, we try to prove that Magda suffers from neurosis, which later develops into psychosis. The serious mental problems in the young lady result from her unsuccesful resolution of her sexual desire towards her own father. Magda's female Oedipus Complex is caused by the absence of the mother figure, the sexual attachment to the father, and the unrevoked hatred toward the mother competitor.
\end{abstract}

Key words: Electra Complex, daddy issues, psychosis, neurosis

John Maxwell Coetzee is an author and academician from South Africa and is now an Australian subject living in South Australia. Coetzee has collected many awards throughout his literary career. His novel Waiting for the Barbarians was awarded the James Tait Black Memorial Prize in 1980. Age of Iron won the Sunday Express Book of the Year award, and The Master of Petersburg the Irish Times International Fiction Prize in 1995. He was the first author to be awarded the Booker Prize twice: first for Life \& Times of Michael K in 1983, and again for Disgrace in 1999 (O'Neil, 2004). On October 2, 2003, the Swedish Academy announced that he would receive the Nobel Prize in Literature, making him the fourth African writer to win the prestigious prize, and the second South African. Coetzee was praised for his "well-crafted composition, pregnant dialogue, and analytical brilliance," while focusing on the moral nature of his work (Swedish Academy, 2003). 
One of his most typical novels is In the Heart of the Country (1999), which narrates the complex relationships that exist between the colonizer and the colonized. It takes place on a barren farm in South Africa and is told through the perspective of an intelligent yet introvert white woman, Magda. Magda is jealous of his old father's mistress, who also happens to be the wife of their servant Henrik. So Magda writes a journal in which she lets her mind flow, describes the plans she makes to assassinate the concubine, and cries for her frustrated desire of becoming a woman. In the midst of this stream of consciousness, she informs readers of how she actually kills her father and has sexual encounters with Henrik. In the end of the story, she has lost her mind, alone in her home in the middle of nowhere.

In this article, we are interested in exposing what psychological problem Magda as the main character of the story experiences and why she suffers from it. We argue that Magda suffers from neurosis and psychosis as a result of the unsuccessful resolution of her sexual desire towards her father. In arguing so, we will employ the psychological theory of psychoanalysis, especially its concept of the female Oedipus Complex.

\section{OEDIPUS COMPLEX IN FEMALES}

Eagleton (1996) suggests that there is a marked relationship between the development of the modern literary theories and the turmoil of the modern era. The turmoil does not exclusively happen in economic, political, and ideological sectors of the society. It also touches people on their most personal and intimate area of life. It is a crisis of human personality, human personality, and human relationship. Those experiences can be naturally found throughout history of mankind. However, it is only in the modern era such experiences are documented and formulated into a systematic field of knowledge, psychoanalysis.

Psychoanalysis was found in Vienna in the late $19^{\text {th }}$ century by Sigmund Freud, "a specialist in nervous diseases" interested in finding the causes of neurotic or hysterical symptoms (Freud, 1950, p. 25). Freud became aware of the existence of unconscious mental processes as a result of his neurological researches in which he found that “... it was not any kind of emotional excitation that was in action behind the phenomena of neurosis but habitually one of sexual nature whether it was a current sexual conflict or the effects of earlier sexual experiences (p. 41). 
The earlier sexual experiences could surprisingly be traced back as far as to the childhood.

Freud believed that the libido developed in individuals by changing its object, a process codified by the concept of "sublimation" (Eagleton, 1996, p. 132). He explained that, as human beings developed, they became absorbed into different and specific objects through their stages of development-first in the oral stage (demonstrated by an infant's pleasure in nursing), then in the anal stage (exemplified by a toddler's pleasure in defecation), then in the phallic stage. The 'phallic' stage begins to focus the boys' libido (or sexual drive) on the genitals (p. 133) Freud argued that boys then passed through a stage in which they focused on mothers as a sexual object and regarded their father as an enemy and competitor for the exclusive love of their mother (p. 134).

Freud hoped to prove that his model was universally valid and thus turned to ancient mythology and contemporary ethnography for comparative material. He named his new theory the Oedipus Complex after the famous Greek tragedy Oedipus Rex by Sophocles, in which Oedipus, who unknowingly kills his father, Laius, and marries his own mother, Jocasta (Freud, 1950).

In his later writings (1920s and 1930s), Freud gave more attention to the Oedipus Complex in females. According to Freud, a girl, like a boy, was originally attached to the mother figure (Eagleton, 1996, p. 135). However, during the phallic stage, when she discovered that she lacked a penis, she became sexually attached to her father, tried to seduce him, and at the same time become more hostile toward her mother. Freud attributed the character of this developmental stage in girls to the idea of "penis envying", where a girl was envious of the male penis (p. 140). According to the theory, this penis envy led to resentment towards the mother figure, which was believed to have caused the girl's "castration", or the girl's disappointment that she had lost her sexual organ (p. 161). The hostility towards the mother was then later revoked for fear of losing the mother's love, and the mother become internalized, much the same as the Oedipus Complex.

Although common usage refers to 'suffering from a female Oedipus Complex', psychoanalysis does not consider the complex a sickness, but instead a perfectly normal stage that all children go through. However, theses desires are thought to remain heavily repressed and unconscious in the minds of all seemingly normal adults. It is held that the unsuccessful 
resolution of the Oedipus Complex could result in neurosis and even homosexuality (p. 135). In popular media, the female Oedipus Complex is often called as 'Daddy Issues'. It refers broadly to the results of a female's turbulent, or abusive relationship with her father, or absence of a father figure during her childhood, and the way in which this problem is said to hinder relationships later in life.

\section{MAGDA AS A NEUROTIC AND PSYCHOTIC WOMAN}

In this section, we are going to identify the symptoms of a neurotic character as seen in Magda. Although it is difficult to define Magda's character trait because it might have existed before we meet her, there are some events showing that she may have been disrupted even at the opening of the novel. She is an unattractive, bitter, self-declared spinster. She calls herself "an angry spinster in the heart of nowhere" (Coetzee 1999, p. 4). And that is not the only time she calls herself a spinster. She angrily claims that she grows up to "fight against becoming one of the forgotten ones of history" (p. 4). She writes her notes and exercises her anger through them. She also rages against her father when he starts to flirt with the servant's wife, Klein Anna. She says:

my rage at my father is simply rage at the violation of the old language, the correct language, that take place when he exchanges kisses and the pronouns of intimacy with a girl who yesterday scrubbed the floors and today ought to be cleaning the windows (p. 47).

The fact that she only exercises her anger on paper rather than truly fights a good fight indicates that Magda also has a low self esteem. For instance, she describes herself as "forgotten, dusty, like an old shoe, or when I have been used, used as a tool, to bring the house to order, to regiment the servants" (p. 44). She also sees herself as "simply a lonely, ugly old maid" (p. 45). This kind of self images has led to her withdrawal from life. When Magda several times calls herself a spinster, she might have suffered from being lonely, no companion. In all her life, she feels that she has been left and forgotten.

Her father's relationship with Klein Anna also grows in this fragile girl excessive anxiety. She despises the possibility of her becoming a servant in her own father's house. In her fantasy, she thinks that in a couple of 
months, she will be bringing her father and her mistress breakfast in bed. She will have to wash out the mistress's soiled underwear (p. 57).

Besides the psychological trails, Magda also displays several physical symptoms of her being neurotic. As the theory says, being a neurosis a person most certainly has physical effects (Neurosis, n.d.). As a mental illness, the term "neurosis" represents a variety of psychiatric conditions in which emotional distress or conflict is expressed through various physical, physiological, and mental disturbances, and which may include physical symptoms. These symptoms do not appear to have a medical cause. In several notes that she writes, she again and again tells that she has the migraines, insomnia and other diseases. She says, "I said once that I slept, but that was a lie." "How can I afford to sleep?" (p. 79). Even, in her exposition to the story, she says: "I was in my room...fighting a migraine' (p. 1). Again in several occasions, she says that her father takes her to her bedchamber with a migraine (p. 37). In his book on about this half-of-the head headache, Sacks (1985) says that in some patients severe migraines may either coexist with severe neuroses, or occur in their place. Paradoxically, the headache may serve as an escape from the psychological conflicts the patients simultaneously conceal and express. They would be most unhappy or would take far more flight into a neurosis if they could not fall sick from time to time.

It does not take a long time for the neurosis to become psychosis. Magda's complete madness is shown when she becomes delusional. Although she does not consider herself a "destroyer" (Coetzee, 1999, p. 47), she has put herself as a "killer" by fantasizing to execute her father. Soon she also wants to eliminate the servant's bride or, rather, she wishes to eliminate both her father and mistress at the same time. She imagines: "I have broken a commandment, and the guilty cannot be bored. I have two full-grown bodies to get rid of besides many other traces of my violence" (p. 12). Magda also imagines the coming of some insects. She is so frightened that she tells Hendrik, her servant and his wife: "We must be aware in general ... of the revival of insect life ... I mention plagues of caterpillars....the wasps, for wasps are predators too" (p. 91). So, she sees things and hears voices that are not there. "In my solitude I hear voices, perhaps I am truly a witch woman” (p. 39). Such delusion and paranoia are severe symptoms of a psychotic person (Psychosis, n.d.). 


\section{MAGDA AND DADDY ISSUES}

Magda's neurosis and psychosis can be traced from her notes in which she reveals the causes albeit in neurotic/psychotic manner. In this section, we are going to discuss the reasons why Magda suffers from the disorders. We believe that Magda experiences the mental disorders due to the unsuccessful resolution of her sexual desire towards her father.

\section{The Absence of a Mother Figure}

As a child develops a healthy, early attachment to a mother figure in his/her psychosexual development, Magda does not; even she can "barely recall her” (p. 2). Her mother is very weak, and she lives unhappily under the oppression of her husband, Magda's father. From her notes as well, we know that her father has demanded from the mother a son to be the heir of the family. And the mother is so frail to fulfill the demand that she dies during the delivery of the baby. It can be said that if there is any early attachment to her mother, it must be a short and insufficient one.

The less attachment to a mother figure leaves Magda with only two choices. First, she can attach herself to any other available motherly figures like a nanny or a grandmother in most cases. Second, she attaches herself to any available figures around her life, which are her father or other males in that male-dominated colonial South Africa. Unfortunately, the motherly figures are not around while the fatherly figures seem to be everywhere. This fact can be seen from the following lamentation: “... mother who drugged me with milk and slumber in the featherbed and then, to the sound of bells in the night, vanished, leaving me alone among rough hands and hard bodies-where are you?” (p. 7). The lamentation does not change the fact that she has been unconsciously attached to the rough hands and hard bodies in her early childhood.

So, we imagine when Magda, like other girls, enters the next stage of psychosexual development, that is when a girl becomes sexually attached to a father figure, she does it unpertubedly. She has acquired a strong attachment to her father, and thus her sexual attachment to her father is logically stronger than other girls with a different situation. So is her desire to be pregnant by him. And this incestious desire has never been revoked like any other girls as she never feels afraid to lose the love of a mother. And from this point it could only go worse. 


\section{Magda's Sexual Attachment to Her Father}

In the previous section, we have analyzed how closely attached Magda to her father is. As a narrator, she tells us between her fantasy and reality that she is sexually attracted to the father. When recounting the story line, we can put the pieces of her fantasy and the reality to be one whole picture that she loves her father. The father, however, does not acknowledge her existence, let alone love her in return. In reality, the setting of colonial South Africa has simply provided a climate of psychological oppression sufficient to make Magda's become neurotic. In an African family, male child is preferred to the female child and is upheld as a "king" (Kambarami, 2006). This situation is not any better in the colonial Africa setting. Since she is a little girl she feels that the father has considered her as an unwanted child. Her father never expects a daughter in such a maledominated enterprise where a son will supposedly survive and perform better.

This unwanted existence causes Magda to experience being a single being despite her living together with her father. Whether she is absent or present in front of the father does not affect him. She says,

To my father I have been an absence all my life. Therefore instead of being the womanly warmth at the heart of this house I have been a zero, null, a vacuum towards which all collapses inward, a turbulence, muffled, grey, like a chill draft eddying through the corridors, neglected, vengeful (Coetzee, 1997, p. 2).

Despite that, it seems that Magda and her father have husband-wife routines that suggest an Electra. For instance, she has the duty to prepare the warm water for her father to bath and makes sure that the hot water has been poured into the bathtub the moment her father comes through the front door. She seems to enjoy this activity especially when she can inhale "the heavy miasma of soap and sweat" and when she thinks of "male flesh, white, heavy, dumb, whose flesh can it be but his?" (p. 9). The comment in itself seems more erotic than filial. And this erotic love can be confirmed from its timeless proof: the arrival of jealousy.

When her father takes the servant's wife as a mistress, Magda cannot help feel as jealous as a lover can do. The fact that she has spied her father's sexual behavior to his mistress proves that she is jealous. She 
watches how "he undresses her and lays her out on his servant's coir mattress” (p. 39). And she weeps “drunken weeping” (p. 39). "Tears roll down my cheeks, my nose is stuffed, it is not good, I wait for the man on the other side of the door to decide for me what form tonight's misery is to take" (p. 56).

Yet, her father consciously and unconsciously never troubles himself to sooth her feeling. Her expectation that the "erotic spell" (p. 58) between two lovers are broken, and that her father would seat her and give her something to drink out of her misery, never happens. As if it is not bad enough, his father now even hurts her physically. One night when she feels helpless and her insomnia attacks her she taps on her father's door just to ask for a comfort. "Daddy... . Can you hear me? ...Daddy, I can't sleep... . Daddy, I'm feeling strange. What shall I do?” (p. 59). The reaction that she gets from her father is not what she has expected. He is so furious that he hurts her arms and elbow. Although there is a gentle tone when he asks her to go to bed, she hears its "angry edge" and knows how "spurious" it is (p. 60).

Yet, that does not make her become sexually cold toward her father, and now she fantasizes of having sex with her father. She fantasizes that she explores the feel of her body sliding out of her and another body sliding in, limbs inside her limbs, mouth inside her mouth (p. 58). When she almost faints, she notes every detail that her father has done to her: "He lays me down. He lifts my feet and pries my shoes off. He smoothes my dress. What more can he do? What more dare he do?” (p. 61). The hopes that she has on her father has even driven her crazier. She has been confused between her own reality as a daughter and her frustration of being sexually untouched. She says:

His hand is on my forehead, the horny hand of a man who bends wire. How tender, how comforting! But what he wants to know is whether I am feverish, whether at the root of my desolation lies a microbe. Should I tell him there are no microbes in me, my flesh is too sour to harbour them? (p. 61).

\section{Magda's Unrevoked Resentment toward Her Father's Mistress}

From the way Magda describes Anna at their first meeting we can see how suspicious she is to the mistress. Magda notices that her father sees "through his heavy-glasses the red kerchief, the wideset eyes, the pointed 
chin, the sharp little teeth, the foxy jaw, the slender body of Hendrik's Anna" (p. 28). The "foxy jaw", for instance, shows how she looks Anna as a deceitful character. Furthermore, she says that Hendrik's bride has "sly doe-eyes" (p. 29) which means tricky eyes. This suspicion turns into hate when it is confirmed that Anna steals her daddy as described in the previous section.

Magda's resentment to Anna is clearly out of jealousy. And yet it is not just a jealousy. It is a psychosexual type of jealousy which determines anybody's psychological well being. In the character of Klein Anna, Magda may find a competitor mother who has been non-existent in her early childhood and is believed to have caused her losing of sexual organ or 'castration'. Magda understands that she may not have a chance to experience the intimate routines with her father anymore. She cannot beat Klein Anna sexually as well as socially. "The slender body" is sexually far more attractive than the "lonely, ugly old maid". This fact has been admitted by Magda when she says: "I could never make him happy, I was never more than the dull dutiful daughter, I only bored him” (p. 111). Socially speaking, her father's relationship to her and Anna are both taboo. Yet somehow we imagine that the society will accept her father's sexual relationship to Anna more easily than his to her. Keeping a mistress is a common practice among colonial masters, and this is certainly deemed a lesser evil than practising incest.

Tragically, Magda cannot revoke her resentment as she realizes this mother-competitor figure is not her real mother. While other girls may neutralize the feeeling of resentment to their mother for fear of losing the mother's love, Magda is certainly not afraid of losing the love of the mother competitor. She knows it too well that Klein Anna will by default secretly despise her. Magda, therefore, never successfully overcomes her female Oedipus Complex. As a result, she cannot perform as a normal subject and does remain anarchic, sadistic, and aggressive like what Eagleton (1996, p. 134) describes about the child in the pre-oedipal stage. And with these, she becomes an ideal daddy-and-mistress killer.

\section{CONCLUSION}

Magda, the main female character in Coetzee's In the Heart of the Country, suffers from neurosis, which later develops into psychosis. The first mental disorder can be seen from both psychological and physical 
symptoms. Psychologically, she is an angry, low self esteemed, and anxious young lady. She also suffers from a terrible headache, which does not have a valid medical cause. The neurosis develops into psychosis when she starts to have delusion such as fantasizing the murder of her daddy and mistress and the coming of insects. The serious mental problems in the young lady result from her unsuccesful resolution of her sexual desire towards her own father. This female Oedipus Complex is caused by the absence of the mother figure, the sexual attachment to the father, and the unrevoked hatred toward the mother competitor.

\section{REFERENCES}

Coetzee, J. M. (1999). In the heart of the country. London: Vintage.

Eagleton, T. (1996). Literary theory: An introduction. Minneapolis: The University of Minnesota.

Freud, S. (1950). An autobiographical study. London: The Hogarth Press \& The Institute of Psycho-Analysis.

Kambarami, M. (2006). Femininity, sexuality and culture: Patriarchy and female subordination in Zimbabwe. South Africa: ARSRC.

O'Neil, P. M. (2004). Great world writers: Twentieth century. London: Marshall Cavendish.

Sacks, O. (1985). Migraine: Understanding a common disorder. California: UCLA Press.

Swedish Academy. (2003). The nobel prize in literature: John Maxwell Coetzee. Retrieved August 02, 2009, from http://nobelprize.org/nobel_prizes/ literature/laureates/2003/press.html

Neurosis. (n.d.). Retrieved July 24, 2010, from http://www.wrongdiagnosis.com/n/ neurosis/

Psychosis. (n.d.). Retrieved July 24, 2010 from, http://www.wrongdiagnosis.com/p/ psychosis/ 